\title{
Isomorphism and the Limits to African Public Financial Management Reform
}

\section{Citation}

Andrews, Matthew. 2009. Isomorphism and the limits to African public financial management reform. HKS Faculty Research Working Paper Series RWP09-012, John F. Kennedy School of Government, Harvard University.

\section{Published Version}

http://web.hks.harvard.edu/publications/workingpapers/citation.aspx?Publd=6596

\section{Permanent link}

http://nrs.harvard.edu/urn-3:HUL.InstRepos:4415942

\section{Terms of Use}

This article was downloaded from Harvard University's DASH repository, and is made available under the terms and conditions applicable to Other Posted Material, as set forth at http:// nrs.harvard.edu/urn-3:HUL.InstRepos:dash.current.terms-of-use\#LAA

\section{Share Your Story}

The Harvard community has made this article openly available.

Please share how this access benefits you. Submit a story.

Accessibility 


\title{
MARVARD Kennedy School JOHN F. KENNEDY SCHOOL OF GOVERNMENT
}

\author{
Faculty Research Working Papers Series
}

Isomorphism and the Limits to African Public Financial Management Reform

\author{
Matt Andrews \\ John F. Kennedy School of Government - Harvard University
}

May 2009

RWP09-012

The views expressed in the HKS Faculty Research Working Paper Series are those of the author(s) and do not necessarily reflect those of the John F. Kennedy School of Government or of Harvard University. Faculty Research Working Papers have not undergone formal review and approval. Such papers are included in this series to elicit feedback and to encourage debate on important public policy challenges. Copyright belongs to the author(s). Papers may be downloaded for personal use only. 


\title{
ISOMORPHISM AND THE LIMITS TO AFRICAN PUBLIC FINANCIAL MANAGEMENT REFORM
}

\author{
Matt Andrews \\ Assistant Professor, Harvard Kennedy School of Government \\ 116 Rubenstein \\ 79 John F. Kennedy Street \\ Cambridge, MA \\ 02138 \\ USA. \\ Matt_andrews@hks.harvard,edu
}

\begin{abstract}
Many reform results fall below expectations in the development arena, especially in the public sector. Do the reforms just need more time to work better, or should we adjust our expectations? In addressing this question, the current article draws from isomorphism to think about potential limits to reform in developing countries. The theory is considered appropriate for thinking about change processes in the developing world. It presents change as motivated more by the need for legitimacy than efficiency and, in identifying the mechanics of change, points to potential limits of such change: to organizational dimensions that are visible, peripheral and involves concentrated sets of professional agents. These limiting factors are applied to a study of public financial management reform in 31 African countries which shows that some dimensions do appear more limited to isomorphic influence than others. Isomorphic change may indeed face natural limits, something the development community should consider in thinking about how it goes about facilitating and motivating reform in its client countries.
\end{abstract}




\section{INTRODUCTION}

What do you do when your mission centers on effecting change in other organizations, you have increased resources to do this, clarified the change agenda, but still see limited change? Public sector reformers in the development community face this question, implicit in evaluations showing that reform is ubiquitous in developing countries, tied to donor engagements, highly similar across dissimilar contexts, and having similarly weak impact, apparently below expectation (World Bank 2008). But what should we really expect from public sector reforms in developing countries?

The current article asks this question in respect of public financial management (PFM) reforms in Africa. The first section shows that these reforms are indeed everpresent on the continent, supported by multilaterals and strikingly alike across countries. Reform similarities reflect a normative model of "good international practice" formalized in a Public Expenditure and Financial Accountability (PEFA) Performance Measurement Framework (PEFA 2006, 5). Recent reviews of PFM reform progress find modest reform results and argue for additional time to ensure more ambitious expectations are met (de Renzio and Dorotinsky 2007).

Section two asks why we would expect greater change over time and if we should rather expect a continuation of the currently observed limits to change. Institutional isomorphism is introduced to address this question. The theory posits that organizations change to gain legitimacy and support in their external environment, not primarily to improve effectiveness (DiMaggio and Powell 1983). Such change is effected through coercion, mimicry and normative transfer and fosters conformity with characteristics defined as appropriate in the organizational environment. But the theory suggests limits to conformity, especially where organizational characteristics: (i) are difficult to observe externally; (ii) are core to the organization; and (iii) involve actors with whom the externally defined change agenda is unlikely to resonate normatively. These ideas inform propositions about which PFM dimensions might be less open to isomorphic influence: those targeting budget execution, requiring de facto change and involving deconcentrated actors less likely to have a normative affinity with change ideas or close proximity to external players driving change. 
Section three presents a methodology for testing these propositions and a discussion of results. Data are from PFM system assessments in 31 African countries, all using the same PEFA framework. The assessments show the degree to which countries conform with "good practice" characteristics in 64 PFM dimensions considered "the immediate objectives of reform" (Wescott 2008, 22). Multivariate ordered logistic regression analysis is employed to test the degree to which this conformity is limited by the type of PFM characteristic. As proposed, reform seems limited in regard to budget execution, de facto and de-concentrated PFM dimensions, even when controlling for key country factors like the length of reform commitment. This supports the idea that isomorphic reform in African PFM is limited.

The article's value lies in the way it builds on recent thinking about the differential impact of isomorphic pressures on change in the broader public management literature. It also constitutes a rare empirical analysis of public management reform in developing countries. The approach and findings should be of peculiar interest to the development community, shedding light on why reforms routinely underperform - in PFM and beyond, extending to topics like externally driven nation building. The concluding section asks what the broadly defined development community could do to engender more successful reform, given the apparent limits to its current model. It focuses on the need to develop internal rather than external pressures, where a different, rational theory of change would see reforms centered on solving problems and ensuring that such problem solving, fraught with learning and failure as it is, becomes the basis of gaining external legitimacy as well.

\section{AFRICAN PUBLIC FINANCIAL MANAGEMENT REFORM}

\section{Ubiquity and Similarity of PFM Reforms}

Change is a central theme of development, and the change agenda in developing countries increasingly focuses on public organizations. A recent World Bank evaluation of public sector reforms in developing countries shows how prominent the agenda has become. ${ }^{1}$ It notes that 11 percent of World Bank loans made between 1990 and 2006

\footnotetext{
${ }^{1}$ Allen and Last (2007) note that the World Bank is but one of 50 different donors providing PFM support in the development context. They indicate that, on average, seven donors work in each country.
} 
included a major public sector reform (PSR) component (World Bank 2008, 21). Two thirds of these loans were made after 1999, when the Bank expanded "to 40 programs per year" (14.5 percent of all projects annually) (World Bank 2008, 21). Public financial management (PFM) dominates this reform agenda with PFM being "a major component of 81 percent" of projects. Projects containing PFM components number over 30 a year since 2000, valued at $\$ 912$ million per year (or 4.7 percent of Bank lending) (World Bank 2008, 28). PFM also routinely provides conditions for other loans (World Bank 2006).

As a continent, sub Saharan Africa had more World Bank public sector reform projects than any other region between 1990 and 2006 (37 percent of the total, with Latin America and the Caribbean second at 22 percent). African countries accounted for nearly half of all global PFM projects since 2000, seeing numbers increase from 22 between 1990 and 1999 to 64 between 2000 and 2006 (World Bank 2008, 28). The similarity of reform agendas reflected in project content and PFM conditionalities across African countries is startling. ${ }^{2}$ A study of 31 African countries (Andrews 2008a) found, for example, that: 28 were pursuing Medium Term Expenditure Frameworks (MTEF); 25 were introducing program, performance or activity-based budgeting; all were adopting Government Financial Statistics (GFS) or Classifications of the Functions of Government (COFOG); 26 were using ceilings to prepare budgets; all were creating Treasury Single Accounts (TSAs) or some consolidated public accounts structure; 20 were tackling a systems project (like FMIS); and all were adopting International Public Sector Accounting Standards (IPSAS) or some other version.

Scholars and practitioners familiar with PFM lingo will identify these as fairly standard technical reforms in the field, commonly mentioned in OECD countries. But the degree to which African PFM reforms seem to conform to these standards is striking, reflected in recent survey findings that, "Top down budgeting is more common in ... Africa than in OECD; African more than ... OECD countries impose ceilings on spending requests; African countries more than ... other groups ... have multi-year expenditure ceilings; and African countries also report more performance targeting" (Doe

\footnotetext{
${ }^{2}$ As a reflection of this issue, The Bretton Woods Project, an NGO critical of the World Bank, titled its response to the PSR evaluation, "Evaluation faults Bank's 'same old formula' for public sector reforms" (Bretton Woods Project 2008).
} 
2008). ${ }^{3}$ The similarities in reform content belie dissimilarities between countries. The 31 country sample alluded to above includes Mauritius, the Democratic Republic of Congo, Mozambique, Sierra Leone, Rwanda and Guinea. The variation in country size, income level and colonial legacy across such group is upstaged only by differences in stability: One country has been stable for 40 years, one came out of a 15 year civil war in 1992, two others experienced conflicts ending in 1994 and 2002, and two endured instability until as recently as 2005 . The different contexts imply different PFM challenges, opportunities and constraints, with some countries having enjoyed long periods of credible annual budgets and others experiencing periods with no budget at all, for example. Even with these dissimilarities, however, one finds similar PFM reforms.

Many of the similar reform elements have been formalized into a Public Expenditure and Financial Accountability (PEFA) Performance Measurement Framework (PEFA 2006, 5). Developed by a multi-donor group, the PEFA framework standardizes an approach to thinking about PFM systems that focuses countries and donors on multiple dimensions Wescott $(2008,22)$ describes as "the immediate objectives of reform." The PEFA assessment is presented as a tool that countries can use to benchmark their system against "existing good international practices" (PEFA 2006, 5). The description suggests a mixture of supposed best practices and normative thinking underlying PEFA and indeed PFM reform approaches. The best practices are apparently drawn from OECD countries, and norms come from various sources, including international accounting bodies (PEFA 2006; Pretorius and Pretorius 2008). Similarities in country reform agendas reflect such thinking and seem to espouse a normative onesize-fits-all model of what an appropriate PFM system looks like.

\section{Reform Results and the Issue of Expectations}

Recent work has used data from PEFA assessments and other sources to examine how African and other countries are progressing in their efforts to establish these 'more appropriate' systems (de Renzio 2008; de Renzio and Dorotinsky 2007; Levy and Kpundeh 2004; Pretorius and Pretorius 2008; Wescott 2008; World Bank and IMF 2006). This work parallels a stream of high-profile evaluations of public sector reform initiatives

\footnotetext{
${ }^{3}$ Andrews (2008b) finds similarly that developing countries are at least as likely to introduce other PFM standards as more developed OECD countries.
} 
as a whole, which have not yielded positive results. World Bank civil service and anticorruption initiatives are generally panned as weak and ineffectual in the 2008

independent evaluation, for example, which gives overall Bank performance in the area a “moderately satisfactory” rating (World Bank 2008, 73). It rates PFM reform as "moderate to highly satisfactory," however, noting that this performance "outweighs the shortcomings in other areas."

Studies on PFM progress in developing countries do report positive progress, either in the form of specific countries scoring better on assessments over time or in better performance across countries in one or other set of PFM dimensions. ${ }^{4}$ All studies similarly report concerns about limits to reform progress as well. de Renzio and Dorotinsky $(2007,12)$ identify Burkina Faso and Tanzania as strong and consistent reformers, for example, but contrast this with "declines" in PFM quality in Benin, Mali, Malawi and Madagascar. de Renzio (2008) implies a positive reform impact on the quality of 'upstream' budget formulation processes in a sample of 57 countries but suggests reform limits in the continued weaknesses of 'downstream' budget execution dimensions. Wescott (2008) notes that while PFM indicator scores have increased across developing countries, these reflect uneven improvements across processes and evidence of improvements in overall PFM system quality and impact on PFM goals is elusive. ${ }^{5}$

Against this story of mixed reform results - and elusive 'real' results - authors are generally quick to cite the need for patience and realistic, time-sensitive expectations. de Renzio $(2008,7)$ comments that reforms in the weaker PFM 'downstream' "take longer" than others. He seems to imply that, with time, we will see African countries realize the expectation of achieving "good international practice" PFM systems in these 'downstream' dimensions as well as the upstream. Such is the apparent thinking behind de Renzio and Dorotinsky's $(2007,21)$ comment that, "Having realistic expectations of the possible rate of PFM system improvement is critical," which leads to the recommendation that, "for donors ... longer-term, sustained commitments to PFM reform

\footnotetext{
${ }^{4}$ All three studies note the need for caution in interpreting results, given the generally weak information on which assessments are based. This noted, the studies have been cited elsewhere as legitimate sources.

${ }^{5}$ For example in a November 2008 workshop at the Overseas Development Institute in London, Wescott stated that, "We did not systematically measure [the] link between PFM improvements and improved service delivery outcomes."
} 
may be a critical element of success." But should we really expect greater change over time, or should we rather expect a continuation of the limited change we now see?

\section{ISOMORPHISM AND LIMITS TO REFORM}

\section{Isomorphism as an Appropriate Theory of Change}

The question is not ignored by de Renzio (2008, 7), who qualifies his reference to the importance of timing by also stating that other non-temporal factors "have prevented 'downstream' systems from being strengthened," including "scarce capacity and donor focus" and "political incentives". These are common scapegoats for public sector reform failure (Andrews and Turkewitz 2005). While commonly bemoaned, however, the development community has yet to explain why these kinds of factors constrain reform, how we might think theoretically about change and change limits, and what should drive our expectations of reform progress.

Public management literature has advanced thinking on change in past decades. While there are many strands of this literature (Fernandez and Rainey 2006), Ashworth, Boyne and Delbridge (2007) suggest two main theoretical approaches that have emerged. The first "rational" perspective suggests that "the characteristics of organizations shift over time in order to pursue substantive performance (e.g., higher efficiency or effectiveness)" (Ashworth, Boyne and Delbridge 2007, 165). The authors tie this perspective to studies on public sector performance (citing articles like Rainey and Steinbauer 1999) and one might further associate it with the more managerial or political approaches to change (including Kotter 1995). At the extreme, this perspective implies that change arises from peculiar responses within organizations to specific performance needs - changes in goals or objectives, for example — and that success requires, primarily, persuading more stakeholders to support rather than oppose the change. Factors like political persuasion are vital to explaining success in this approach, which suggests that organizations will adopt different, contextually relevant organizational solutions.

The second perspective is "an alternative view ... offered by institutional theory, which argues that the primary objective of organizational change is not better substantive performance but greater legitimacy" (Ashworth, Boyne and Delbridge 2007, 165). Called 
isomorphism, this approach emerged in the work of Meyer and Rowan (1977) and DiMaggio and Powell (1983) who identified that organizations gain legitimacy and resources by conforming to societal expectations, which leads organizations in similar fields to become similar. The basic idea is that organizations exist within fields- - "those organizations that, in aggregate, constitute a recognized area of institutional life" (DiMaggio and Powell 1983, 148) - and face pressure to conform to the externally defined "belief systems and related practices that predominate" such fields (Scott 2001, 139). If organizations do not yield to these isomorphic pressures, they lose legitimacy and jeopardize their external support and survival (Ashworth, Boyne and Delbridge 2007, 167). Over time, organizations thus change to reflect what the field defines as more appropriate structures, systems and institutional characteristics. As summarized by Frumkin and Galaskiewicz $(2004,285)$, "Organizations do not always embrace strategies, structures, and processes that enhance their performance but, instead, react and seek ways to accommodate pressures following external scrutiny and regulation." The authors go on to describe a problem called de-coupling, whereby institutional isomorphism sees organizations "pursuing practices that may have little to do with maximizing efficiency" which means that "structure may be decoupled from the organizational mission."

The rational perspective seems well suited to explain change in goal-driven and goal-dependent organizations (with clear goals and unambiguous relationships between goals and the means to achieve these goals) in fields open to variable 'fitted' solutions and alternative organizational models. Isomorphism, in contrast, emerges as a relevant theory where organizations are highly dependent on other organizations, uncertain about which institutional structures to adopt, face ambiguous goals, and are in organizational fields with a small number of dominant, statist players (on which many organizations are dependent), few accepted organizational models and high levels of uncertainty and ambiguity (Chang 1998; DiMaggio and Powell 1983; Frumkin and Galaskiewicz 2004; Meyer and Rowan 1977, 349; Ramanath 2008). While a mouthful, this last sentence lists characteristics that were discussed earlier in context of PFM reform initiatives in Africa, where governments are dependent on donors, face great goal ambiguity (or ambiguity about the means to achieve goals like fiscal discipline and allocative and technical 
efficiency, or the MDGs ${ }^{6}$ ) and are thus uncertain as to what their PFM structures should look like (which leads organizations to resort to best practices as a 'safe' reform option). Similarly, the PFM field in development is small, dominated by one or two donors that fund most activities, and espouses a fairly tight normative model (now manifest, perhaps, in PEFA).

Given the overlap of characteristics noted above, isomorphism seems the more appropriate perspective to apply to the question at hand, thinking about the expectations we should have for PFM reform progress in Africa. Theoretical ideas about the pressures underlying isomorphic change are particularly helpful building blocks in shaping such reform expectations and, indeed, identifying potential reform limits.

\section{Isomorphic Mechanics and Limits}

The literature identifies three types of pressures through which isomorphic change processes work: coercive, mimetic and normative (Ashworth, Boyne and Delbridge 2007; DiMaggio and Powell 1983). ${ }^{7}$

Coercive pressures involve one organization exerting power and influence over another to force the adoption of preferred structures or institutions, often through political and legal means or by controlling resource access. Highly dependent, politically vulnerable organizations are particularly susceptible to such pressures. Mimetic pressures center on the influence of 'best' or 'good' practice on the structural choices an organization makes. These manifest in the tendency some organizations have to emulate or copy what appear to be desirable or accepted practices, even if these have not been proven effective. Organizations dealing with uncertainty are particularly vulnerable, especially when uncertainty clouds the relationship between organizational means and

\footnotetext{
${ }_{7}^{6}$ Millennium Development Goals.

${ }^{7}$ These pressures can be exerted on organizations as a whole or on agents within the organizations, given that many studies of isomorphism are conducted under the auspices of an "expanded" new institutionalism (Bagdadli and Paolini 2005, 2) which incorporates aspects of broad social as well as narrow agent engagement in explaining change. The active engagement of managers and leadership in mediating the environment is thus embraced, and isomorphic influences are not seen as working through agent-less processes of organizational osmosis (see also Ezzamel et al. 2005). Covaleski and Dirsmith (1988) provide an important study that makes this point and examines the roles of power and individual interest in the context of institutional change to budgeting and financial management systems in US universities.
} 
ends, complicating the choice of means. ${ }^{8}$ Normative pressures "describe the effect of professional standards and the influence of professional communities on organizational characteristics" (Ashworth, Boyne and Delbridge 2007, 167). They are particularly strong where a professional grouping accredits certain practices, establishing them as norms.

All three sets of pressures are evident in the African PFM reform field (and development more generally). Politically vulnerable, resource poor governments are highly dependent on donor organizations, which offer support on condition of specific types of PFM reform. The reform designs are often influenced by "good international practice" that countries appear willing to replicate because of a dearth of local solutions to the problems they face. PFM is also an area dominated by professionals, from accountants to auditors and other groups bent on standardization. These professionals, mostly working in donor organizations, have become central to the growing PFM field in development. They have contributed to the emergence of the PEFA assessment tool, which is an important standardizing device that establishes the normative legitimacy of a set of practices and characteristics, inferring the need for governments to adopt such.

But are all organizational characteristics - in PFM and beyond — similarly open to these institutional pressures? Ashworth, Boyne and Delbridge (2007, 170-171) ask this question pointedly in their 2007 paper, and find reasons to answer 'no'. 9 The authors cite studies that find change limited in respect of some characteristics and, in their own study of local government change in the United Kingdom, they explore how isomorphic influence varies across organizational characteristics. ${ }^{10}$ They conclude that varying influence shows varying "levels of support for institutional theory ... across organizational characteristics" (Ashworth, Boyne and Delbridge 2007, 183). The current

\footnotetext{
${ }^{8}$ This is one way of explaining problems with the MDGs. The goals are appealing but also difficult to achieve, and it is unclear that the development community knows how to achieve them. Hence the operations focused on their achievement seem to have become characterized by best practice type interventions: Given the ambiguity surrounding which means will help achieve the ends, and uncertainty about actually achieving these ends (and thus failing to gain the legitimacy associated with this) managers seek legitimacy through the kinds of processes they adopt (best practices). If these means fail to yield the desired ends, the managers can 'blame' the best practices and do not lose legitimacy personally or for the organization.

${ }^{9}$ Ramanath (2009) asks the question in a recent paper as well, in regard to NGO change.

${ }^{10}$ Although the type of variation they find runs counter to initial hypotheses, as discussed at other points in this article.
} 
article holds rather that institutional theory can explain such evidence, if one thinks about limits to the coercive, mimetic and normative pressures.

\section{Visibility and Isomorphic Change Limits}

As a starting point, for example, it seems that visibility or tangibility is central to the mechanics of isomorphism and that not all organizational characteristics are visible or tangible. Ezzamel et al. $(2005,3)$ describes this quality as "rendering activities visible and 'thinkable'," stressing how important it is to see something, assess it and respond to it in establishing new cognitive structures, a hallmark of institutionalism and isomorphism (Zucker 1991, 105). The idea emerges in work on organizational change as well, where Meyer and Rowan (1977, 343-344) emphasize the importance of external "prescriptions" that "display[s] responsibility" often through visible ceremonies and symbols. They also argue that, "Organizational characteristics may vary in the degree to which they are subject to, or susceptible to, symbolic representation externally." Wuthnow et al. $(1984,50)$ indicate that these influences work best where organizational constructs are "comprehensible" while Clingermayer and Feiock (2001) stress the centrality of "visible programs" and DiMaggio and Powell $(1991,183)$ suggests that isomorphic change is all about "appearances." The argument is pretty simple:

Isomorphic influence requires that external parties exerting influence, and internal parties being influenced, can describe, package and evaluate the relevant characteristics of the organizational dimensions being influenced.

Imagine how hard it is to coerce someone to do something you can't really describe and/or know you won't be able to evaluate. It is also difficult to identify something as best practice without visibility. Frandale and Paauwe $(2007,369)$ make this basic point in arguing that organizations adopt practices "they observe ... in other organisations." It is even complex to set a normative standard, about operations or even ethics, without visibility. DiMaggio and Powell $(1991,35)$ state as such in discussing the importance of cognitive processes in profession-induced change, emphasizing the role of reasoning and the tangible grounds of reason: classifications, representations, scripts, schemas, etc. In discussing the impact of accounting norms on organizations Ezzamel et 
al. $(2005,36)$ emphasize the importance of "specific cognitive mechanisms for visualization and cognition".

The reality is that organizations have many non-visible processes where isomorphic influences are limited. Jepperson (1991) speaks of these as the backstage social processes that play a different role to the more visible, institutionalized elements of formal structure. Whereas formal structures are more symbolic and central to establishing organizational legitimacy, social processes play "a more literal role in helping the organization achieve its technical mission": "Less visible to external constituents, these social processes are often called instrumental to denote an intimate relationship with the technology used by the organization to perform its tasks" (Fogarty and Dirsmith 2001, 248). Wildavsky emphasized these less visible social processes, referring to underlying "politics of the budgetary process" as deeply influential on how systems work, but lamented that they are not always visible, and difficult for reformers to grasp and influence. He distinguished between formal and "practical" budgeting, for example, saying that the latter takes place "in a twilight zone between politics and efficiency" (Wildavsky 1992, 598). He saw the lack of knowledge abut these processes as a key limit on reform prospects: "Until we know something about the 'existential situation' in which the participants find them- selves ... proposals for major reform must be based on woefully inadequate understanding" (Wildavsky 1992, 598).

\section{Core-ness and Isomorphic Change Limits}

Wildavsky $(1992,598)$ also pointed out that budget and financial management reforms seem limited to changes at the organizational periphery, arguing that we are not 'even able to guess' at the impact of more intrusive reforms:

A [reform] proposal which alters established relationships ... which changes prevailing expectations about the behavior of key participants, or which leads to different calculations of an agency's fair share, would have many consequences no one is even able to guess at today.

The fact that this kind of proposal is apparently rare reflects on another suggested limit to isomorphic influence: Such influence will focus on and affect peripheral more than core organizational characteristics, mostly because efforts to influence core characteristics through coercion, mimicry or normative transfer will likely encounter major opposition. 
Such opposition, while still problematic, is assumed to be less influential when it comes to endogenously determined 'rational' change, because such change can be shown to link to organizational meaning, reflected in a focus on outcomes that organizational stakeholders care about.

This is the basic hypothesis introduced (but not ultimately proven) by Ashworth, Boyne and Delbridge $(2007,171)$ who argue that "some organizational attributes are resistant to, or can be protected from, isomorphic pressures." The authors cite various studies in presenting the idea. Kirkpatrick and Ackroyd (2003) argue, for example, that externally induced change is less effective when characteristics are associated with core practices that preserve organizational values (and are therefore subject to greater protection). Miles and Snow (1978) emphasize such limits when it comes to changing the practices embedding "what we believe and what type of organization this is." Pinnington and Morris (2003) actually find limited external influence over practices associated with the "interpretive scheme" of the organization.

In using the word "core" to describe characteristics that may be less susceptible to isomorphic change, Ashworth, Boyne and Delbridge tap into a rich vein of thought in organizational theory. Hannan and Freeman $(1984,156)$ noted two decades ago that, "The view of organizations as having a core which is more difficult to modify than more peripheral parts of its structure is not new" and cite Parsons (1960), Thompson (1967) and Downs (1967) as examples of prior argument. Hannan and Freeman suggest that the core involves much more than an "organization's identity and value system" (suggested by Ashworth, Boyne and Delbridge). They emphasize four "core aspects" starting with an organization's de facto mission (the most core, which derives from and informs organizational values, strategy and allocative modalities), its authority structure, technology, and marketing strategy (Barnett and Carroll 1995, 224). These are differentiated from "what Scott calls peripheral structures, the detailed arrangements by which an organization makes links with its environment and tries to buffer its ... core" (Hannan and Freeman 1984, 157).

Hannan and Freeman $(1984,157)$ present these peripheral structures as "more plastic than the core set" of organizational characteristics: "They can be transformed 
because attempts at changing them involve relatively little moral and political opposition." They argue that change to the core can lead to organizational demise, hence shoring up significant resistance to change. While these assertions have been tested with mixed results (Barnett and Carroll 1995; Ashworth, Boyne and Delbridge 2007) they provide an intuitively important set of perspectives as to why isomorphic change may be limited to some organizational characteristics (at the periphery) rather than others (at the core). It seems immensely plausible that, in the words of Bagdadli and Paolini $(2005,2)$, many organizations will limit change to the periphery because of the fear that, "If organizations attempt to integrate institutional prescriptions and their backstage processes, they may provoke conflicts both within and outside themselves and threaten their survival." "Hannan and Freeman's $(1984,155-156)$ example as to why "some parts of organizations change more quickly than others" presents the rationale:

Universities ... are constantly changing the textbooks used for instruction... Persuading a university faculty to abandon liberal arts for the sake of vocational training is something else.

Why would the university's curriculum be so difficult to change? A number of answers come quickly to mind. The curriculum embodies the university's identity ... [its] statement of purpose ... The curriculum also represents one of the bases on which resources are distributed. A change ... threatens entrenched interests.

The example evokes the role of both sociological measures (maintaining values crucial to the group identity) with agency measures (protection of interests, especially related to resource flows) in entrenching core processes and making these characteristics more resistant to change: "The curriculum is difficult to change, then, because it represents the core of the university's organizational identity and underlies the distribution of resources across the organization" (Hannan and Freeman 1984, 156). The authors seem to address

\footnotetext{
11 de Vasconcelos and de Vasoncelos $(2003,185-186)$ found this to be the case in research on change towards ISO9000 human resource management principles: "The propositions we formulated regarding ISO9000 consulting models and the change management dynamics they entail are the following: the more an ISO9000 implementation process generates significant changes in the organization's social system, the more the organization is likely to face resistance to change; the less an ISO9000 implementation process generates significant changes in the organization's social system, the less the organization is likely to face resistance to change." The authors appropriately conclude that, "These propositions suggest that the extent of the social change produced by ISO9000 is an important issue" but note that "ISO9000 consultants, [as showed in their survey], generally ignore this factor."
} 
the issue of what change to expect in concluding that curricular change is limited because, "It can be said to lie at the university's "core""

\section{Profession-deficiency, De-concentration and Isomorphic Change Limits}

A final argument as to why isomorphic change might be limited in certain organizational areas relates to the professionalization and concentration of actors.

Professionalization is a staple of isomorphism literature and emerges as the basis of normative pressure itself: "Much of the pressure for [normative] change stems from the increased number of professionals being employed" (Slack and Hinings 1994, 819). Professionalized individuals help to transmit external ideas into organizations because they have similar orientations (DiMaggio and Powell 1983, 152), hold similar ideological positions, view things through the same cognitive lens, and have similar ideas about "the most appropriate organizational design to realize" a purpose (Slack and Hinings 1994, 820). Professionalization also leads to the "filtering of personnel" whereby entry to specific organizational positions is guarded by professionals evoking normative selection criteria. ${ }^{12}$ This ensures strong professional presence at the top of many organizations, which establishes concentrations of "people with similar values and beliefs about the purpose and design" of the organization (DiMaggio and Powell 1983, 152).

Professionalized people also have greater access to information about better practices and will probably have a greater affinity towards these and stronger cognitive abilities to make sense of them (a common framework for thinking through what they see). This facilitates 'best practice' transfer, enhancing mimetic pressure in a way that can also ensure such practices are shaped to local climes, which may even involve 'legitimizing' local versions of these practices. In the words of Greenwood, Suddaby and Hinings (2002, 58): "Professional associations ... play an important role in theorizing change, endorsing local innovations and shaping their diffusion."

'Profession proficiency' thus stimulates isomorphic change whereas 'profession deficiency' undermines isomorphic change by weakening normative and mimetic pressures. Ezzamel et al. $(2007,29-30)$ find this as a problem in regard to budgeting and

\footnotetext{
${ }^{12}$ Ghoshal $(1988,70)$ also emphasizes 'normalizing' those not from the profession, whereby new staff "undergo anticipatory socialization to a set of expectations and standards of appropriate behavior."
} 
accounting reforms in the United Kingdom, especially pertaining to the role of politicians. They found that "Only a small number of politicians ... tended to have either accounting/finances background or extensive experience in the public sector..." which limited their affinity towards new budget and accounting practices as well as their cognitive abilities to engage with the new practices and information. Many resorted to describing these new practices and information forms as "a mystery" (Ezzamel et al. 2007, 29). The lack of professional affinity undermined change, manifesting in "a lack of interest in, or ability to comprehend" the new approaches which "may in itself [have] encourage[d] politicians to treat financial information as less relevant to their deliberations" (Ezzamel et al. 2007, 30).

'Concentration' is a second, related dimension of this final argument and derives from the observation that some change dimensions center more on small, concentrated cadres than others. These concentrated interventions lend themselves to stronger isomorphic influence because it is easier (i) to coerce smaller, more proximately located and interested groups, (ii) to facilitate access for concentrated groups to better practice examples (and to promote cognitive understanding of these), and (iii) to accommodate normative transfer with smaller groups. Where change requires engagement and cooperation of groups that are de-concentrated - professionally, geographically, organizationally - coercive, mimetic and normative transfer is much more complicated and one is more likely to see variation in organizational practice and limits to externally defined, on-size-fits-all normative change. This kind of observation helps Ghoshal (1988) explain why scanning activities are more similar across a small set of tightly knit Korean firms (all influenced by the same consulting company) than a highly diffuse set of American firms (getting their ideas from multiple sources), for example.

When change is focused on a de-concentrated set of actors, the capacity for influence and reach is diminished. The likelihood that de-concentrated players occupy overlapping fields is also stronger, undermining field-specific isomorphic influences. These impacts emerge in Ezzamel et al.'s study (2007) on accounting reform in devolved UK governments, where concentrated entities in the executive managed to comply with isomorphic requests to develop plans, complete with financial data, but de-concentrated sets of parliamentarians have been less receptive of the change (as noted). The 
concentrated groups are presented as being more directly affected by the new responsibilities (for devolved governments to develop strong plans), and the practices and "culture" of planning with numbers and using new accounting methods. The deconcentrated population of parliamentarians responsible for analyzing these plans is said to be less influenced by the external demands, best practices or "culture", difficult to assemble and to 'get on the same page'. Even where there were professionals in these parliamentary groups, the overall support for change was low. ${ }^{13}$

Similar experiences are recounted by Lapsley and others in research on accounting reforms in the UK's National Health Service (NHS). Reforms were driven by financial managers and accountants who ran into an inertial force in the form of nonfinancial managers, physicians (especially those holding budgets) and managers in distributed units (Lapsley and Wright 2004). Central entities ensured at least a ceremonial perception of compliance with accounting and reporting standards when they aggregated information received from these non-financial budget holders (where compliance was significantly lower). The de-concentration here was thus within the organization (a central reporting office was dependent on multiple budget holders' reports) and across professions. Change limits emerge because of the latter issue with regard to general management models in the health sector generally, where research shows "the tensions and difficulties of shifting from a consensus management model in health care management to a unitary manager as an authority figure ... particularly because of the difficulties of integration of different professional groupings" (Lapsley 2008, 79).

\section{Propositions about Expected Limits to PFM Reform in Africa}

The argument is that isomorphic influence will be weaker where organizational characteristics or dimensions: (i) are difficult to observe by external parties (the visibility issue); (ii) are core to the organization (the core-ness issue); and (iii) involve actors with whom the externally defined change agenda is unlikely to resonate normatively, or who are difficult to reach and coordinate to achieve change (the profession-deficiency and deconcentration issue). The three problems are hardly exclusive of each other: many core

\footnotetext{
${ }^{13}$ The more professional members did gain some credibility and power, however.
} 
processes lack visibility, for example. ${ }^{14}$ Together, the three contribute to propositions about where isomorphism might face 'natural limits' in African PFM reform.

\section{P1: Isomorphic influence is more limited in downstream budget execution dimensions than upstream budget making dimensions}

The idea is that 'upstream' planning and budget preparation processes and products are more visible and peripheral than 'downstream' processes. ${ }^{15}$ Hence the upstream processes are more susceptible to isomorphic influence. This idea has a fairly long history in institutional literature, with various papers presenting formal budgets and plans (and their processes) as important "rituals of reason" organizations use to engage with their environment, declaring their rationality (Czarniawska-Jorges and Jacobsson 1989). Ezzamel et al. $(2007,32)$ argue that, "With their rule-like characteristics, budgets are presented ... as ideals of rationality, but beneath that veneer budgets are no more than a myth in the process of being institutionalized." Organizations will produce plans and budgets because, "Creating a myth of compliance with such rational systems can endow ... bodies with legitimacy."

One can certainly see the development community entrenching this mode of thought, in the emphasis placed on Poverty Reduction Strategy Papers (plans) to access resources, and on the near-universal use of loan conditions centered on adopting more structured and rational budgets. Seabright (as discussed in Lensink 2003, 416) identifies a version of this behavior as a "bias to focus on routine tasks" which "would probably provide an incentive to focus on ensuring that budgets are spent, rather than focusing on whether they are well spent." The problem is that the literature suggests potential decoupling between these more visible, ceremonial PFM dimensions and the real processes of resource allocation (in the budget execution downstream).

Schick $(1998,128)$ wrote that, in developing countries especially, "The government has two budgets: the public one that is presented to the parliament and the real one that determines which bills are paid and how much is actually spent." $\mathrm{He}$ suggests that the latter budget is only revealed in the execution process and is markedly

\footnotetext{
${ }^{14}$ Suggesting that visibility may in fact be endogenous, dependent on the core-ness of the dimension.

15 This is not to say that all downstream dimensions are opaque and core.
} 
different from its formal partner: "The formal budget is known in advance, the informal one after the spending." Pettersen (1995) tells a similar story of health budgeting in Norway, where she finds "systematic decoupling" between budgets and budget processes and actuals and actual processes. She discusses how the decoupling arises because of visibility and core-ness issues. On the one hand, for example, health administrators are willing to abide by formal budget processes and even stand by formal budget products in order to gain public support. On the other hand, the self-same administrators speak of having their "real budgets" in their desks and suggest that they will not allow the formal version to threaten their mission. Montes and Andrews (2005) have similar findings in a study of budget reform in Bolivia, where they argue that the differential impact of donor influence on peripheral reforms can actually exacerbate the de-coupling effect. The argument, in short, is that organizations are more ready to update their budget making than their budget execution anyway, and donor pressure on the former only exacerbates the imbalance in focus.

P2: Isomorphic influence is more limited on de facto PFM dimensions than de jure (or other procedural) dimensions

De jure change is more susceptible to isomorphic influence because it is more visible and peripheral, as well as more normatively based (especially when adopted in a best practice format, which Murrell suggests is the norm) ${ }^{16}$ Shirley $(2005,17)$ alludes to the first issue in explaining why donors cannot really impact institutions in a de facto sense, picking up on both time and evaluation aspects of visibility: "They [donors] also prefer changes that can be instituted rapidly and be easily used as benchmarks for dispersing funds and assessing outcomes. This results in a focus on de juri rather than de facto change. De facto change is often slower, and is usually only measurable after the project is ended, if at all." Beyond visibility, many also suggest that developing country governments may be open to adopting laws and other formal de jure procedural changes because they perceive them as peripheral, not really affecting the organizational core. They expect that business will continue as usual, according to the entrenched informal

\footnotetext{
${ }^{16}$ Murrell (as discussed in Lensik 2003, 416) argues that, in a principal-agent relationship, "the contractor [agent] needs to develop a law that is as close as possible to Western standards [the norm]" and that "donor principal can only observe de jure law, i.e. the formal statute on the books."
} 
system they know to have de facto influence. Schick (1998, 127-128) captures the issue in his description of developing country civil service systems:

Many developing countries have formal management control systems that prescribe how government should operate ... On paper everything is done according to rule ... Formal rules dictate every step in the hiring process ... [which] is monitored by a central agency to assure compliance with the rules.

Where informality flourishes, however, this is not the way many civil servants get their jobs. They are hired because they know the right person or have contributed to some organization or cause ... Thus there are two coexisting civil service systems - one based on formal rules, the other on actual practices.

Schick $(1998,128)$ notes that these informal systems are considered wholly appropriate and legitimate in many contexts: "To say that there is an informal system is not to conclude that the rules always are ignored or that corruption always flourishes, although these pathologies may occur. Rather, it is to argue that the informality contributes to public order; in the case of the civil service, it enables the government to recruit and retain skilled persons." We should expect that laws will be accommodated quite readily in reforms where such formal institutions are seen as peripheral, decoupled from the informal systems actually regulating an organization. ${ }^{17}$ Such decoupling is not always evident or extreme (Covaleski and Dirsmith 1988) but it is commonly alluded to in developing countries: McCourt and Ramgutty-Wong (2003) reference it in the case of Mauritius, for example, where civil service hiring is formally presented as merit based and efficient but accounts of actual bureaucratic structures suggest a different, more informal reality; Marcel Fafchamps (1996) shows that practice differs from formal rules in Africa's private sector as well, with Ghanaian firms contracting through informal ties instead of formal, legal mechanisms, even where these exist.

Where laws and processes are not de-coupled from the core, one would expect them to be extremely risky reform conditions or goals - and probably not adopted as such by external donors concerned about project disbursement. Given the focus of such players on peripheral de jure change, one might actually argue that their reform demands

\footnotetext{
${ }^{17}$ Mummert (2002) presents a related explanation why governments might agree to adopt a de jure reform at one level but de facto adoption requires deeper engagement. He says that de facto reforms "Depend primarily on micro-level process[es] inside the recipient countries and their organizations" and not on the instrumental variables that aid agencies control through isomorphic pressures.
} 
routinely draw attention away from core de facto change needs and hence efficiency and effectiveness-enhancing change.

P3: Isomorphic influence is more limited in PFM dimensions involving deconcentrated sets of actors

Normative PFM models increasingly suggest a key role for central players in a top-down relational structure. The central players include budget offices, treasuries, tax agencies, and procurement and internal audit regulatory entities. These players are often the direct counterparts in loan agreements, reform projects and the like, small in size and populated with the most 'professionalized' people in the system. Through their international connections, these people also enjoy greater access to international best practice than others in the system, like budget officers in line ministries and accountants and procurement officers in municipalities. We should therefore expect more successful change when reforms are concentrated in the hands of these players, more susceptible to coercive, mimetic and normative isomorphic influence.

We should expect more limited change when de-concentrated actors are more involved. As noted, de-concentration can be geographic, professional or organizational. The more de-concentrated a change engagement is, the greater the number of players who are not directly influenced by coercive pressures (because they are not engaged in loan negotiations, for example), mimetic pressures (because they do not get to see best practices, or do not have the same cognitive resonance with best practices), or normative pressures (because they are not affected by the same professional influence and in many instances are subject to other normative persuasion). In a sense, then, the problem is simply one of limited isomorphic reach. This is a large PFM problem, however, as the normative model in vogue centralizes regulation but de-centralizes implementation-so there is a big role for line ministries, agencies, and local governments. These are the exact players we would expect isomorphic pressures not to reach. 


\section{TESTING THE PROPOSITIONS}

\section{Data and Variables}

As already mentioned, the PFM field in international development has taken shape in the past decade, symbolized by the Public Expenditure and Financial Accountability (PEFA) Performance Measurement Framework. The PEFA framework was developed in 2003 by a group of donors prominent in this field. It lists 73 key PFM dimensions (organized into 31 indicator areas) described as "critical" to the "performance of an open and orderly PFM system" and "the key PFM elements ... recognized as being critical for all countries to achieve sound public financial management" (PEFA 2006, 2). Table 1 lists some of these dimensions, ${ }^{18}$ which Wescott $(2008,22)$ describes as "the immediate objectives of reform". Countries receive ordinal scores in each of the dimensions (from A to D) where an A represents 'good international practice', ostensibly a point of optimal convergence for all governments. Scores below A imply different degrees of compliance with the norms or progress towards achieving this point, as the example in Table 2 shows.

Table 1. Examples of PEFA PFM dimensions

\begin{tabular}{|c|c|}
\hline Dimension number & Basic dimension description \\
\hline PI-11i & Existence of and adherence to a fixed budget calendar \\
\hline pi-11ii & $\begin{array}{l}\text { Clarity/comprehensiveness of and political involvement in the guidance on the } \\
\text { preparation of budget submissions (budget circular or equivalent). }\end{array}$ \\
\hline PI-11iii & Timely budget approval by the legislature or similarly mandated body \\
\hline PI-12i & Preparation of multi -year fiscal forecasts and functional allocations. \\
\hline PI-12ii & Scope and frequency of debt sustainability analysis \\
\hline PI-12iii & $\begin{array}{l}\text { Existence of sector strategies with multi-year costing of recurrent and investment } \\
\text { expenditure. }\end{array}$ \\
\hline PI-12iv & Linkages between investment budgets and forward expenditure estimates. \\
\hline
\end{tabular}

Table 2. Criteria for Dimension PI-12(iii)—Existence of costed sector strategies

Score $=A$ : Strategies for sectors representing at least $75 \%$ of primary expenditure exist with full costing of recurrent and investment expenditure, broadly consistent with fiscal forecasts.

Score $=$ B: Statements of sector strategies exist and are fully costed, broadly consistent with fiscal forecasts, for sectors representing $25-75 \%$ of primary expenditure.

Score $=\mathrm{C}$ : Statements of sector strategies exist for several major sectors but are only substantially costed for sectors representing up to $25 \%$ of primary expenditure OR costed strategies cover more sectors but are inconsistent with aggregate fiscal forecasts.

Score $=\mathrm{D}$ : Sector strategies may have been prepared for some sectors, but none of them have substantially complete costing of investments and recurrent expenditure.

\footnotetext{
${ }^{18}$ The full PEFA tool (PEFA 2006) shows all of these dimensions, organized into indicator areas.
} 


\section{Dependent and Key Explanatory Variables}

The PEFA data represents externally defined reform goals (the basis of isomorphism) and shows how far countries have come in reaching such goals. 64 dimension scores were used for 31 African countries to construct the dependent variable for analysis in a panel data set. ${ }^{19}$ There were 1918 values for this dependent variable, the country score in a PFM dimension for a specific country, after 66 were found legitimately missing in a quality control assessment.: ${ }^{20} 37$ Percent of the scores were Ds (coded as 1 , as per the convention established in de Renzio (2007)), 31 percent were Cs (or 2), 20 percent were Bs (or 3), and 11 percent were As (or 4). The research centered on testing whether these PFM dimension scores reflected the limits identified in the research propositions - in the PFM downstream, and involving de facto change and de-concentrated sets of players.

The PFM dimensions were coded to identify three dummy variables representing these three dimension types. ${ }^{21}$ Dimensions were coded as downstream if they did not relate to planning, budget preparation and legislative analysis of the prepared budget. Dimensions were coded as 'de facto' if a C could not be achieved without de facto behavioral change. ${ }^{22}$ Dimensions were coded as de-concentrated if a $\mathrm{C}$ could not be achieved without the involvement of a de-concentrated set of actors (like line ministries, local governments, or multiple state owned enterprises).

\footnotetext{
199 dimensions were dropped because they related to outcomes and donor practices. 31 PEFA assessments had been conducted in Africa up to June 2008, when the data was collected. Africa was chosen as a focal area for a number of reasons, including the fact that quality control of the data was onerous and thus limited the size of the data set. A limited data set is arguably more useful if it is anchored in some common factor, hence the focus on Africa as a region. The countries included in the sample were Benin, Burkina Faso, Cameroon, Central African Republic, Comoros, Congo, Cote d'Ivoire, Democratic republic of the Congo, Ethiopia, Gabon, Ghana, Guinea, Guinea Bissau, Kenya, Lesotho, Madagascar, Malawi, Mali, Mauritania, Mauritius, Mozambique, Nigeria, Rwanda, Senegal, Siera Leone, Sao Tome and Principe, Swaziland, Tanzania, Togo, Uganda and Zambia.

${ }^{20}$ This involved checking that each score was valid. All of the 31 countries had PEFA scores for most dimensions, but some were missing, as well as a Public Financial Management Performance Report (PFMPR) which gave the rationale and evidence for scores. This allowed the researchers to ensure that scores were well backed up by the written description in the PFM-PR and equated with the criteria set out in the PEFA tool. In doing so, 66 scores were ultimately recorded as legitimately missing because the PFM-PRs indicated that the dimension was not reviewed. Francophone countries had more missing variables than Anglophone and missing variables were more common in areas like internal and external audit than others. ${ }^{21}$ Three coders were involved, working blindly to establish reliable dummies.

${ }^{22} \mathrm{C}$ was chosen as a benchmark here because it appears the crucial point of differentiation between stronger and weaker dimensions in Africa: where the 'limit' to change is most evident. Many of the dimensions coded as de jure allow B scores also on the basis of weak de facto evidence as well—asking rather for evidence of legal or procedural change.
} 
Table 3 shows the proportions of different dimension types as well as the average scores in each type. ${ }^{23}$ Dimension types to the right are those where 'isomorphic limits' are proposed to be most severe and we should expect less change. The table shows that they have lower average scores, suggesting some support for the research propositions. Table 4 disaggregates the types even more, and shows that dimensions characterized by the 'limiting' factors (downstream, de facto and de-concentrated characteristics at the lower right) have the lowest averages, and dimensions at the opposite extreme (characterized by factors proposed as most conducive to isomorphic reform) have the highest averages (Upstream, de jure, concentrated, at the top left).

Table 3. Proportions and means of different PFM dimension types

\begin{tabular}{|cccccc|}
\hline Dimension type & $\%$ dimensions & $\begin{array}{c}\text { Average } \\
\text { (out of 4) }\end{array}$ & Dimension type & \% dimensions & $\begin{array}{c}\text { Average } \\
\text { (out of 4) }\end{array}$ \\
\hline Upstream & 25 & 2.29 & Downstream & 75 & 1.89 \\
De Jure & 41 & 2.30 & de Facto & 59 & 1.97 \\
Concentrated & 41 & 2.32 & De-concentrated & 59 & 1.88 \\
\hline
\end{tabular}

Table 4. Proportions and means for different PFM dimension types, disaggregated

\begin{tabular}{|c|c|c|c|c|c|}
\hline Dimension type & $\begin{array}{c}\% \\
\text { dimensions }\end{array}$ & $\begin{array}{l}\text { Average } \\
\text { (out of } 4 \text { ) }\end{array}$ & Dimension type & $\begin{array}{c}\% \\
\text { dimensions }\end{array}$ & $\begin{array}{l}\text { Average } \\
\text { (out of } 4 \text { ) }\end{array}$ \\
\hline $\begin{array}{l}\text { Upstream, de Jure, } \\
\text { concentrated }\end{array}$ & 11 & 2.52 & $\begin{array}{l}\text { Downstream, de Jure, } \\
\text { concentrated }\end{array}$ & 17 & 2.23 \\
\hline $\begin{array}{l}\text { Upstream, de Jure, } \\
\text { de-concentrated }\end{array}$ & 6 & 2.36 & $\begin{array}{c}\text { Downstream, de Jure, } \\
\text { de-concentrated }\end{array}$ & 4 & 2.06 \\
\hline $\begin{array}{l}\text { Upstream, de facto, } \\
\text { concentrated }\end{array}$ & 2 & 1.87 & $\begin{array}{l}\text { Downstream, de facto, } \\
\text { concentrated }\end{array}$ & 11 & 2.32 \\
\hline $\begin{array}{l}\text { Upstream, de facto, } \\
\text { de-concentrated }\end{array}$ & 6 & 1.94 & $\begin{array}{c}\text { Downstream, de facto, } \\
\text { de-concentrated }\end{array}$ & 40 & 1.77 \\
\hline
\end{tabular}

\section{Other Controls}

These differences in means do not prove conclusively that the proposed isomorphic limits exist, even though t-statistics show significant differences in mean between various types. One has to wonder how other factors influence the scores and if the influence of dimension type disappears when considering these other factors. This is ultimately what one would expect if change processes reflected the 'rational' approach suggested by Ashworth, Boyne and Delbridge (2007). In this approach change is pursued to improve

\footnotetext{
${ }^{23}$ There is some overlap across these variables, reflected in correlations of 0.33 between the downstream and de facto dummies, 0.11 between the downstream and downstream and de-concentrated dummies and 0.48 between the de facto and de-concentrated dummies. This is not considered a major problem in the quantitative analysis proposed, given the large number of observations.
} 
effectiveness and efficiency and is thus contextually influenced (by specific goals, constraints and opportunities). One would expect these goals, constraints and opportunities to vary across countries and hence would expect different countries to score differently across the dimensions. Countries emerging from conflict, lacking any budgetary framework in recent years or without a legacy of accounting and reporting, would be expected to score differently to countries with no history of conflict and a legacy of having budgets and financial reports, for example. Reform limits would be different in different countries, not centered on the same dimension types in all (as in the proposed isomorphic limits).

A set of variables were identified to control for country factors. The first was the LENGTH OF REFORM COMMITMENT. As argued, authors like de Renzio and Dorotinsky (2007) suggest that PFM change takes time, so a longer reform commitment should be positively associated with reform progress. An ideal variable would reflect the time a country has continuously committed to reforming each PFM dimension. It is impossible to identify time commitment at the dimension level, however, and it is also difficult to identify the exact start date of committed reforms (given that reforms start and stop). It is possible to identify when the countries in the sample formalized a Poverty Reduction Stragey Plan (PRSP), however, which was intended to consolidate PFM and other reforms, and entrench commitment to reform. As a proxy variable, it is used under the assumption that countries with longer PFM reform agendas were also earlier PRSP developers. This assumption is obviously not always correct, but it is interesting to note the overlap between countries de Renzio and Dorotinsky (2007) identify as more experienced with PFM reforms and those introducing early PRSPs: ${ }^{24}$ Burkina Faso and Tanzania are examples (both having the maximum 6 year PRSP). ${ }^{25}$ Countries these authors identify as late PFM starters (or continuing laggards) like São Tome had later PRSP adoption times (having 0 years at the time of PEFA assessment).

\footnotetext{
${ }^{24}$ The PFM-PRs for most countries also routinely mention the PRSPs as important vehicles for PFM reform. Even where countries did not have a PRSP in place at the time of the PFM-PR, most country analyses discussed how PRSPs were envisaged to facilitate a more coordinated PFM reform program.

${ }^{25}$ de Renzio and Dorotinsky explicitly mention the issue of commitment in the case of Burkina Faso, titling a box, "Burkina Faso: Long history of PFM reforms and better ownership as drivers of success?" They do note that the reforms in Burkina Faso predated the PRSP (as they did in Tanzania) but it is important to note that Burkina Faso's early PFM start is mirrored by an early PRSP start, so the PRSP variable should be a valid proxy for PFM reform commitment.
} 
Two variables were included to reflect the impact of economic conditions on reform progress at the country level. A dummy shows which countries were LOW INCOME (with incomes per capita below $\$ 1,000$ per annum). ${ }^{26}$ Thirteen countries fitted this description, and in keeping with prior research (notably de Renzio 2008) we would expect weaker change in these countries - given the assumption of higher reform demand and capacity in higher income countries. ${ }^{27}$ Per capita INCOME GROWTH is also included, reflected as total growth recorded between 1996 and $2006,{ }^{28}$ with the expectation that strong growth records will also have accompanied strong PFM reform pressure and potentially facilitated reform capacity-development at the same time. Mozambique had the maximum ten year growth at 70\% while Guinea Bissau was the lowest at $-32 \%$ (the average was $14 \%$ ).

Three more variables were included to control for socio-economic and historical differences between countries. The first, FRANCOPHONE, is a dummy to show which countries had either French or Belgian colonial heritage. Some commentators note a bias in PFM and other normative governance models towards Anglophone systems (in PFM this is particularly emphasized in regard to the role of external auditors and legislatures). One might well expect weaker reform progress in Francophone countries as a result. ${ }^{29}$ Weaker performance is also expected from politically fragile and resource dependent (often called rentier) states. Nine countries in the sample were classified as FRAGILE (by the IMF), ${ }^{30}$ each having experienced major political upheaval and conflict in the prior 5 year period. One would expect the FRAGILE dummy to have a negative impact on PFM dimension scores because of the major difficulties with reforming in politically traumatic periods and with limited capacity. The RESOURCE dummy reflects the four countries

\footnotetext{
${ }^{26}$ Based on World Development Indicator (WDI) data for income per capita in 2005. A dummy was preferred to a continuous variable because of a limited variation in the sample above and below $\$ 1,000.14$ of the 18 countries above $\$ 1,000$ had per capita GDP below $\$ 2,000$ while 11 of the 13 countries below $\$ 1,000$ were in the band between $\$ 600$ and $\$ 1,000$.

${ }^{27}$ de Renzio $(2007,11-12)$ records a statistical finding that, "countries with a higher level of income perform better in terms of the quality of their PFM systems, both in terms of overall average and for each budget dimension, excluding policy-based budgeting." He suggests that, "This might be related to the growing focus on 'checks and balances' that is associated with higher levels of per capita income, or more simply with the fact that richer countries have more resources to devote to improving PFM systems."

${ }^{28}$ Again based on World Development Indicator data.

${ }^{29} 16$ countries had Francophone colonial legacies in the sample.

${ }^{30}$ Guinea-Bissau, Togo, Central African Republic, Comoros, Sao Tome and Principe, Guinea, Democratic Republic of Congo, Cote d'Ivoire, and Sierra Leone.
} 
classified as oil-rich (based on the IMF classification), ${ }^{31}$ an extreme case of rentier state that receives its revenues from opportunistic sources, and is thus expected to have little incentive to reform. ${ }^{32}$

There are significant correlations between pairs of these control variables. The most prominent relationships emerge between the RESOURCE dummy and the LOW INCOME dummy (with a -0.52 spearman correlation coefficient), the LOW INCOME dummy and the LENGTH OF REFORM COMMITMENT (0.46) and the LENGTH OF REFORM COMMITMENT and INCOME GROWTH variables $(0.53) .{ }^{33}$ These correlations raise concerns about using all the variables in a multivariate analysis, with the major problem being a loss in explanatory power for one or more of the variables because of overlap. One might, however, anticipate the large sample size (over 1900 observations in the panel data set) to partially overcome collinearity concerns.

\section{Method of Analysis and Results}

To quantify effects of the identified variables on the PFM dimension scores in particular countries, multivariate ordered logistic regressions were fitted in the context of the partial proportional odds model. The model was chosen since the dependent variable is a fourcategory ordinal outcome (A, B, C or D). Using multinomial regression would mean that the ordinal nature of the outcome variable is discarded, and not treating this variable as ordinal would result in a loss of efficiency. The partial proportional odds model is a special case of the generalized ordered logit model that is less restrictive than the proportional odds model, which assumes parallel slopes. This assumption was tested in preliminary analysis, using the Brant test, which showed an overall violation of the parallel regression assumption $\left(\chi^{2}=60.1, P\right.$-value $\left.=0.000\right)$ on a number of covariates.

Using gologit2 in STATA (Williams 2005), one generates results in Table 5, which shows coefficients instead of odds ratios (how the results are often shown) because the coefficients are most effective in presenting the idea of a limit (the idea implicit in the research propositions). The results essentially show three sets of coefficients from binary

\footnotetext{
${ }^{31}$ Congo, Gabon, Nigeria and Cameroon.

${ }^{32}$ The rentier state label actually holds for states that receive most of their revenue from non domestic tax and debt sources. If one considers trade taxes and AID, only 3 of the 31 countries in the current sample would not be classified as rentier states.

${ }^{33}$ All of the noted correlation coefficients were significant at 0.01 .
} 
logit models where the categories of the outcome variable have been collapsed into two in each model (because of the violation of parallel slopes): The extreme left shows a panel of coefficients that can be interpreted as those from a binary logit regression where the dependent variable is recoded as D versus scores above D (A,B or C). Positive coefficients here mean that higher values of the explanatory variable push a score towards higher categories on the dependent variable (A, B or C). Conversely, negative coefficients mean that higher values on explanatory variables limit a score to the current category or lower ( $\mathrm{D}$ in the extreme left panel). In respect of the propositions presented, a negative coefficient thus suggests a limit to African PFM reform.

Table 5.Coefficients for partial proportional ordered logistic regression model

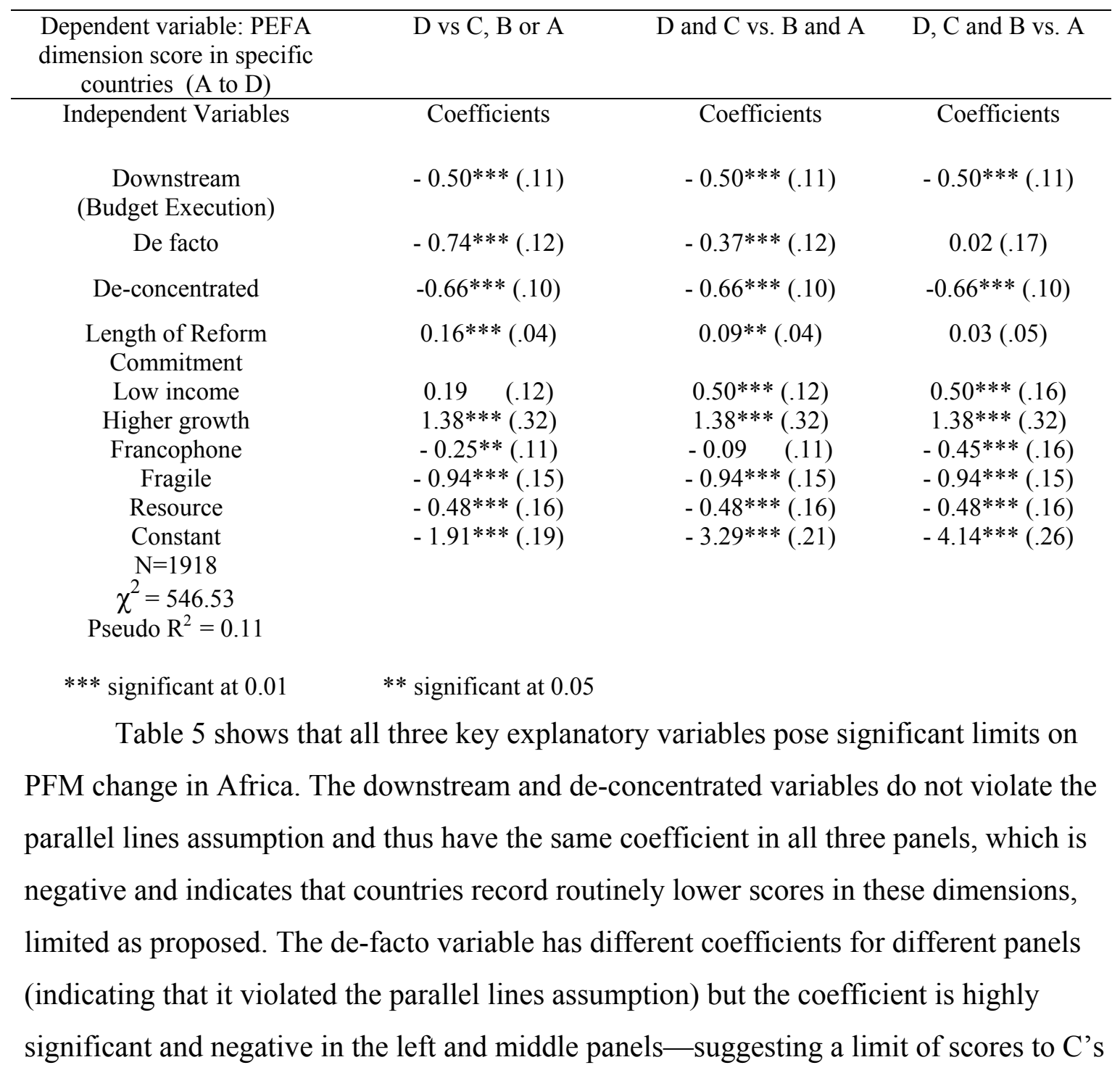


and D's in dimensions requiring de-facto behavioral change. The coefficient is particularly high in the left panel, indicating a tendency for de-facto dimensions to score at the extreme low level-D. The odds ratios for these equations are shown in Annex A and reveal that downstream dimensions were routinely 61 percent more likely to face a limit to lower scores than upstream dimensions. De-concentrated dimensions were 52 percent more likely than concentrated dimensions to face limits to lower scores. De-facto dimensions were 48 percent more likely to face a limit to a $\mathrm{D}$ score, and 31 percent more likely to face a $\mathrm{C}$ limit, than de-jure dimensions. It is important to note that these effects are evident even though country factors are controlled for, suggesting that the limits hold across a varied set of circumstances and are not simply felt in low income, low growth or fragile countries.

At the same time, the county factors show up as significant too (even with collinearity concerns). A longer country-level reform commitment has a positive effect in determining whether PFM dimension scores are above D and C (but not beyond). PFM dimension scores are actually likely to be above $\mathrm{C}$ and even above $\mathrm{B}$ in lower income countries (bucking expectations) and are likely to be in higher categories in highergrowth countries (as predicted). The surprisingly positive impact of low income status could actually reflect isomorphism (as these countries have higher levels of donor engagement and pressure). A Francophone legacy seems to have extreme effects on PFM dimension scores, increasing the tendency to score at $\mathrm{D}$ (the negative coefficient in the left panel) and to score A (the positive coefficient in the right-most panel). As expected, fragility and resource dependence are related with lower dimension scores and hence PFM reform progress.

\section{CONCLUDING DISCUSSION}

This article started by asking what one should do when attempts to effect change in other organizations yield results below expectation. It asked the question in context of PFM reform in Africa and suggested a common answer: It takes time, and with time we will see greater results. But a counter argument was posed, that even with time reforms might face systematic limits, given the approach to change in the development field. 
Isomorphism was introduced as a framework well suited to understanding change in this field, theorizing that organizations like developing country governments accept change in order to attain legitimacy (and ensure continued external support). By deconstructing the framework and focusing on limits to the mechanics of isomorphic influence-coercion, mimicry and normative transfer - the article identified three propositions about isomorphic limits to PFM reform in Africa: In budget execution and de facto and deconcentrated dimensions. The basic argument is that we should expect reform limits in these areas, across all contexts, given the isomorphic nature of development reform approaches.

Table 5 shows the results of a quantitative analysis that suggests there is some validity to this argument. PFM 'progress' is limited in the proposed dimensions across highly different country contexts, even when controlling for these contexts (including length of reform commitment). This finding hints at a potentially important problem for PFM reform and indeed for other change imperatives in developing countries: civil service reform, nation building, and such. As long as isomorphic influences are primarily relied upon to effect change, change will be limited to that which can be seen, is peripheral, and involves narrow client groups. The perception that PFM reforms are more successful than others seems to arise from observations about dimensions that are open to isomorphic influence: Having budget laws and calendars, producing multi-year budget documents, producing standardized accounts, and so forth. These dimensions are in the stronger scoring areas in Table 4, but tell very little of the overall PFM story: 40 out of the 64 dimensions used in the current analysis are downstream, de-facto and deconcentrated - the most limited dimension type with a significantly lower average score across the countries.

Perhaps evaluations cannot relate visible PFM improvements to overall outcome gains because of limits in these more numerous dimensions? Perhaps these kinds of limits are even more prominent in civil service reform and anti-corruption, giving such reform agendas little scope for showing good form (few elements of these reforms are not core, for example, and many dimensions of both reform types are arguably executed by deconcentrated rather than concentrated entities)? The perception that PFM reform is more successful than other reform types may thus reflect the greater openness of some PFM 
reform dimensions to isomorphic influences, even though many PFM dimensions are less susceptible to these influences (and PFM reform itself is as limited as other types - in a real sense). How can reform designs effect change in these less susceptible dimension areas, in PFM and other areas (like civil service)?

The first potential response is to try and get as much out of isomorphic influences as possible, through more aggressive and focused coercion and better approaches to facilitating mimicry and normative transfer. In some areas tight coupling might mean that a coercive intervention at the periphery has real effects on the core (Bagdadli and Paolini $(2005,18)$. Ashworth, Boyne and Delbridge (2007) suggest this may be possible in process oriented organizations (like many governments), where some processes embody and reflect organizational values. The key is to identify which visible, peripheral and concentrated dimensions might accommodate 'tight coupling' to less visible and more fundamentally core practices (often involving de-concentrated players) and then use coercive mechanisms to influence these as primary entry points. External development partners can also accommodate mimicry that goes beyond forced, mindless replication of 'best practices'. Communities of practice can allow similarly positioned managers access to each other and facilitate dialog about doing things better. The result may be less one of copying and more of 'fitting' external ideas to contexts. Normative transfer is a peculiar area of great opportunity in developing countries, given the weakness of professions and thus capacity to build and build-upon such: Rwanda has just created its Institute of Certified Public Accountants, Benin's Accounting Profession was founded in 2006 and has 45 members, and Burkina Faso's ONECCA emerged in 1996 and has 54 members. Building on these professions can yield normative transfer benefits vital to improving cognitive change transfer.

The reality of change is that many entry points for the development community are in this 'isomorphic influence arena' - with centralized players and on the periphery. Interestingly, Hannan and Freeman $(1984,157)$ actually find these entry points fundamental to change anyway, saying that "Changes in core structures usually require adjustment in the peripheral structures." But development partners must be careful not to simply work in these areas, which will exacerbate isomorphic limits and could impose 'external legitimacy traps' on client countries (focused on doing change for legitimacy 
and not for internal efficiency). The end goal must be to try and foster change fitting the 'rational' approach advocated by Ashworth, Boyne and Delbridge (2007). This change focuses on real problems in the target organization and sees change addressing such problems. Such change can reach the invisible core of the organization, given that it helps advance organizational values. One can think of PFM reform introduced to specifically improve the timeliness of salary payments (something core to most organizations) or to improve delivery of a service considered crucial to a community (perhaps facilitating more transparent and efficient funding to birthing services in a high maternal mortality region). This 'rational' approach involves introducing change to solve problems agreed upon and felt within an organizational field and will probably result in different, contextually fitted solutions (instead of normative PEFA-like reforms).

Figure 1. A continuum of change approaches, and challenges for development

\section{Rational change approach:}

Change emerges within organization to make organization more efficient and effective

\section{Isomorphic change approach:}

Change emerges as organizations adopt new practices to look legitimate
(2) Explore approaches to spark more problem-oriented, rational change

(1): Maximize effect

Figure 1 shows these proposals as adjustments to the approach development practitioners take to change. The figure presents a change continuum between the two distinct types introduced by Ashworth, Boyne and Delbridge (2007): rational and isomorphic. This paper finds that isomorphic change alone is quite limited, but that limits can be contained to some degree by maximizing coercive, mimetic and normative influences (intervention 1 in the figure). Limits will only be effectively addressed by moving towards the rational approach in some way, however (intervention 2). This involves focusing less on the technicality of normatively acceptable change (a la isomorphism) and more on the adaptable challenge implied in making organizations more efficient and effective. Interesting examples that combine rational and isomorphic 
influence include competitive isomorphism, which Orr, Woolsey Biggart and Hamilton $(1992,62)$ notes involves the use of some isomorphic influence to make organizations more effective, and the blend of best practice and best-fit contingent approaches (which Frandale and Paauwe (2007) find drives much human resource management change in multinationals). The common idea here is that change is led by an identification of problems requiring change (not the simple reproduction of technical solutions to change) around which coalitions and local solutions emerge. These solutions are likely to be influenced by external practice, given that the wheel is seldom re-created, but this process of adapting processes is not about replication for replication's sake. It centers on internal rather than external change motivation, not external coercion. The continuum extremes could be merged if development organizations like the World Bank can give countries legitimacy for solving their problems (no matter how quirky the solutions), tightening the coupling between what countries need to be better managed (rational change) and what they gain legitimacy for (isomorphic change).

\section{ANNEX A}

\begin{tabular}{|c|c|c|c|}
\hline $\begin{array}{l}\text { Dependent variable: PEFA } \\
\text { dimension score in specific } \\
\text { countries (A to D) }\end{array}$ & $\mathrm{D}$ vs $\mathrm{C}, \mathrm{B}$ or $\mathrm{A}$ & $\mathrm{D}$ and $\mathrm{C}$ vs. $\mathrm{B}$ and $\mathrm{A}$ & $\mathrm{D}, \mathrm{C}$ and $\mathrm{B}$ vs. $\mathrm{A}$ \\
\hline Independent Variables & $\begin{array}{c}\text { Odds ratios with } \\
\text { confidence intervals }\end{array}$ & $\begin{array}{c}\text { Odds ratios with } \\
\text { confidence intervals }\end{array}$ & $\begin{array}{c}\text { Odds ratios with } \\
\text { confidence intervals }\end{array}$ \\
\hline $\begin{array}{c}\text { Downstream } \\
\text { (Budget Execution) }\end{array}$ & $0.61 * * *(0.49,0.75)$ & $0.61 * * *(0.49,0.75)$ & $0.61 * * *(0.49,0.75)$ \\
\hline De facto & $0.48 * * *(0.37,0.61)$ & $0.69 * * *(0.54,0.87)$ & $10.2 \quad(0.73,1.42)$ \\
\hline De-concentrated & $0.52 * * *(0.37,0.61)$ & $0.52 * * *(0.37,0.61)$ & $0.52 * * *(0.37,0.61)$ \\
\hline $\begin{array}{l}\text { Length of Reform } \\
\text { Commitment }\end{array}$ & $1.18 * * *(1.09,1.26)$ & $1.09 * * *(1.02,1.17)$ & $1.03 \quad(0.95,1.13)$ \\
\hline Low income & $1.20 \quad(0.95,1.52)$ & $1.64 * * *(1.30,2.07)$ & $1.64 * * *(1.19,2.26)$ \\
\hline Higher growth & $3.96 * * *(2.12,7.41)$ & $3.96 * * *(2.12,7.41)$ & $3.96 * * *(2.12,7.41)$ \\
\hline Francophone & $0.77 * *(0.62,0.97)$ & $0.92 \quad(0.73,1.14)$ & $1.56 * * *(1.13,2.16)$ \\
\hline Fragile & $0.39 * * *(0.29,0.52)$ & $0.39 * * *(0.29,0.52)$ & $0.39 * * *(0.29,0.52)$ \\
\hline $\begin{array}{c}\text { Resource } \\
\mathrm{N}=1918 \\
\chi^{2}=546.53 \\
\text { Pseudo } \mathrm{R}^{2}=0.11\end{array}$ & $0.62 * * *(0.45,0.86)$ & $0.62 * * *(0.45,0.86)$ & $0.62 * * *(0.45,0.86)$ \\
\hline$* * *$ significant at 0.01 & $* *$ significant at 0.05 & & \\
\hline
\end{tabular}




\section{REFERENCES}

Allen, R. and D. Last. 2007. "Low-Income Countries Need to Upgrade Financial Management.” IMF Survey, 36(11): 170-171.

Andrews, M. 2008a. PFM reform strategy: What role for donor agencies? Isomorphism and the limits of PFM reform. Presentation at Overseas Development Institute Conference on Reforming for Results. 12-13 November 2008. Available at: http://www.odi.org.uk/events/2008/11/12/295-presentationssession-4.pdf

Andrews, M. 2008b. Good Government Means Different Things in Different Countries. Harvard Kennedy School Working Paper No. RWP08-068. Available at SSRN: http://ssrn.com/abstract=1314437.

Andrews, M. and J. Turkewitz. 2005. Introduction to Symposium on Budgeting and Financial Reform Implementation. International Journal of Public Administration 28 (3-4): 203-211.

Ashworth, R., G.Boyne and R. Delbridge. 2007. Escape from the Iron Cage? Organizational Change and Isomorphic Pressures in the Public Sector. Journal of Public Administration, Research and Theory 19: 165-187.

Bagdadli, S. and C. Paolini. 2005. The Institutional Change of Italian Public Museums Between Legitimacy and Efficiency: Do Museum Directors Have a Role? Mimeo. Available at: neumann.hec.ca/aimac2005/PDF_Text/BagdaliS_PaolinoC.pdf

Barnett, W and G. Carroll. 1995. Modeling internal organizational change, Annual Review of Sociology, 21: .217 - 236.

Bretton Woods Project. 2008. Evaluation faults Bank's 'same old formula' for public sector reforms. Posted on web site on 17 June 2008. Available at: http://www.brettonwoodsproject.org/art-561842

Chang, H.J. 1998. Korea: The Misunderstood Crisis. World Development, 26 (8) 15551561.

Clingermayer,J.C and R.C. Feiock. 2001. Institutional constraints and policy choice. Albany, NY: SUNY Press.

Conner, P. and F. Thompson. 2006. Response to Managing Successful Change in the Public Sector. Public Administration Review, 66 (2),26-30.

Covaleski, M and M. Dirsmith. 1988. An institutional perspective on the rise, social transformation, and fall of a university budget category, Administrative Science Quarterly, 33: 562-87.

Czarniawska-Jorges, B. and B.Jacobsson. 1989. Budget in a cold climate. Accounting, Organizations and Society. 12 (1-2): 29-39.

de Renzio, P. and W. Dorotinsky. 2007. Tracking Progress in the Quality of PFM Systems in HIPCs. Washington: The PEFA Secretariat. 
de Renzio, P. 2008. Taking Stock: What do PEFA Assessments tell us about PFM systems across countries? Unpublished mimeo.

de Vasconcelos, I and F. de Vasconcelos. 2003. ISO9000, Consultants and Paradoxes: a Sociological Analysis of Quality Assurance and Human Resource Techniques. RAC, 7 (1): 173-194.

DiMaggio, P. J. and W.W. Powell. 1983. The Iron Cage Revisited: Institutional Isomorphism and Collective Rationality in Organizational Fields. American Sociological Review, 48:147-160.

DiMaggio, P. J. and W.W. Powell. 1991. Introduction. The New Insitut

Doe, L. 2008. The 2008 World Bank/CABRI/OECD Survey of Budgeting Practices and Procedures in Africa and Asia. IMF PFM Blog entry October 24, 2008. http://blog-pfm.imf.org/pfmblog/2008/10/the-2008-world.html

Dorotinsky, W. 2002. HIPC Poverty-related Expenditure Tracking Assessment; Assessment Approach, Results, and Lessons. Washington: The World Bank.

Downs, A. 1967. Inside Bureaucracy. Boston: Little, Brown.

Ezzamel, M., N. Hyndman, Å. Johnsen, I. Lapsley, J. Pallot. 2007. Experiencing institutionalization: the development of new budgets in the UK devolved bodies. Accounting, Auditing \& Accountability Journal, 20(1): 11-40.

Fafchamps, M. 1996. The enforcement of commercial contracts in Ghana. World Development, 24(3): 427-448.

Frandale, E. and J. Paauwe. 2007. Uncovering Competitive and Institutional Drivers of HRM Practices in Multinational Companies. Human Resource Management Journal 17(4): 355-375.

Fernandez, S. and H. Rainey. 2006. Managing Successful Organizational Change in the Public Sector. Public Administration Review, 66 (2): 1-25.

Fogarty, T.J. and M.W. Dirsmith. 2001. Organizational socialization as instrument and symbol: an extended institutional theory perspective, Human Resource Development Quarterly, 12(3): 247-66.

Frumkin, P., and J. Galaskiewicz. 2004. Institutional isomorphism and public sector organizations. Journal of Public Administration Research and Theory 14:283307.

Ghoshal, S. 1988. Environmental Scanning in Korean Firms: Organisational Isomorphism in Action. Journal of International Business Studies, 19 (1): 69-86

Greenwood, R, R. Suddaby, and C. Hinings. 2002. Theorizing change: The role of professional associations in the transformation of institutionalized fields. Academy of Management Journal 45:58-80.

Hannan, M. T., and J. Freeman. 1984. Structural inertia and organizational change. American Sociological Review 49:149-64. 
Jepperson, R.L. 1991. Institutions, Institutional Effects, and Institutionalism in The New Institutionalism in Organizational Analysis, edited by W. W. Powell, DiMaggio. Chicago: University of Chicago Press: 143-163.

Kotter , J.P . 1995. Leading Change: Why Transformation Efforts Fail. Harvard Business Review, 73 (2): $59-67$.

Kirkpatrick, I., and S. Ackroyd. 2003. Transforming the professional archetype? The new managerialism in UK social services. Public Management Review 5:511-31.

Lapsley, I. 2008. The NPM Agenda: Back to the Future. Financial Accountability \& Management, 24 (1): 77-96.

Lapsley, I. and E. Wright. 2004. "The diffusion of management accounting innovations in the public sector: a research agenda." Management Accounting Research 15: $355-74$.

Lensink, R. 2003. The Institutional Economics of Foreign AID (A book review of Mummert, Murrell and Seabright's text). Journal of Development Economics, 72(1): 413-417.

Levy, B. and S. Kpundeh. 2004. Building State Capacity in Africa. Washington: The World Bank.

McCourt, W. and A. Ramgutty-Wong. 2003. "Limits to strategic HRM: the case of the Mauritian civil service" International Journal of Human Resource Management 14, 4: 600-618.

Meyer, J. and B. Rowan. 1977. Institutional Organizations: Formal Structure as Myth and Ceremony. American Journal of Sociology, 83: 340-63.

Miles, C., and R. Snow. 1978. Organizational strategy, structure and process. New York, NY: McGraw Hill.

Montes C, Andrews M. 2005. Implementing Reforms in Bolivia: too much to handle. International Journal of Public Administration 28(3-4): 273-290.

Orr6, M., N. Woolsey Biggart and G. C. Hamilton. 1992. Organizational Isomorphism in East Asia," in Walter W. Powell and Paul J. DiMaggio, eds., The New Institutionalism in Organizational Analysis. Chicago and London: The University of Chicago.

Parsons, T. 1960. Structure and Process in Modern Society. Glencoe, IL: Free Press.

PEFA. 2006. Public Expenditure and Financial Accountability (PEFA) Performance Measurement Framework. Available at www.pefa.org

Pettersen I. J. (1995): Budgetary control of hospitals - ritual rhetorics and rationalized myths? Financial Accountability and Management, 11(3): 207-221.

Pinnington, A., and T. Morris. 2003. Archetype change in professional organizations: Survey evidence from large law firms. British Journal of Management 14:85-99.

Pretorius,C. and N. Pretorius. 2008. Review of Public Financial Management Reform Literature. London: DFID. 
Rainey, H. and P. Steinbauer. 1999. Galloping Elephants: Developing Elements of A Theory of Effective Government Organizations. Journal of Public Administration Research and Theory, 9: 1-32.

Ramanath, R. 1999. Limits to Institutional Isomorphism. Nonprofit and Voluntary Sector Quarterly, 38 (1): 51-76.

Schiavo-Campo, S. 2008. Of Mountains and Molehills: "The" Medium-Term Expenditure Framework. Paper presented at the Conference on Sustainability and Efficiency in Managing Public Expenditures Organized by the East-West Center and Korea Development Institute Honolulu, Hawaii, 24-25 July 2008.

Scott, W.R. 2001. Institutions and Organizations. Thousand Oaks, CA: Sage.

Schick A. 1998. Why most developing countries should not try New Zealand reforms. The World Bank Research Observer 13: 123-131.

Shirley, M. 2005. Can AID reform institutions? Ronald Coase Institute Working Paper No. 6. (April 2005).

Slack, T. and C. Hinings. 1994. Institutional Pressures and Isomorphic Change: An Empirical Test, Organization Studies, 15: 803-27.

Thompson, J.D. 1967. Organizations in Action. New York: McGraw-Hill.

Wescott, C. 2008. World Bank Support for Public Financial Management: Conceptual Roots and Evidence of Impact. World Bank Independent Evaluation Group Working Paper. Available at SSRN: http://ssrn.com/abstract=1169783

Wildavsky, A.1992. Budgeting as a cultural phenomenon. In Jack Rabin (Ed.), Handbook of public budgeting. New York: Marcel Dekker: 51-56.

Williams, Richard. 2005. Gologit2: A Program for Generalized Logistic Regression/ Partial Proportional Odds Models for Ordinal Variables. Retrieved May 12, 2005 (http://www.nd.edu/ rwilliam/stata/gologit2.pdf_).

World Bank. 2006. Review of Development Policy Lending: Review of PFM Issues and Fiduciary Arrangements. Financial Management Sector Board Mimeo. Washington: The World Bank.

World Bank. 2008. Public Sector Reform: What Works and Why? Independent Evaluation Group Evaluation. Washington, D.C.: World Bank.

World Bank and IMF. 2006. Heavily Indebted Poor Countries (HIPC) Initiative and Multilateral Debt Relief Initiative (MDRI)—Status of Implementation. Washington: The World Bank and IMF.

Wuthnow, R., J.Davison Hunter, A. Bergesen, and E. Kurzweil. 1984. Cultural Analysis: The Work of Peter L. Berger, Mary Douglas, Michel Foucault, and Jürgen Habermas. London: Routledge and Kegan Paul.

Zucker, L.G. (1991). The Role of Institutionalization in Cultural Persistence. In Powell,W.W. and DiMaggio P.J. (Eds.). The New Intuitionalism in Organizational Analysis. Chicago: The University of Chicago Press: 83-107. 
